\title{
EFFECT OF PROGESTERONE WITHDRAWAL ON TIME OF OESTRUS AND MATING BEHAVIOUR IN FEMALE RATS
}

\author{
L. L. DOYLE* AND M. T. GLEGG \\ Department of Animal Husbandry, University of California, \\ Davis, California, U.S.A.
}

(Received 10th October 1960)

\begin{abstract}
Summary. Sixteen mature female rats were injected subcutaneously with $10 \mathrm{mg}$ of progesterone daily for 14 days. After 7 days from start of treatment, all animals showed persistent dioestrous vaginal smears. By the 3rd day after withdrawal, most animals showed a pro-oestrous smear. When placed with males at this time, twelve of the sixteen treated females mated as indicated by the presence of spermatozoa in the vaginal smear or by the presence of normally cleaved ova, as compared to only one of five of the oil-injected controls. These results, when compared to the mating percentage of normal colony animals, indicate a significant improvement of mating following withdrawal of progesterone treatment.
\end{abstract}

\section{INTRODUCTION}

In many species, progesterone at sufficiently high levels has been shown to inhibit ovulation, a response presumably associated with an inhibition of the release of pituitary ovulating-hormone. On the other hand, progesterone withdrawal is followed by an induced ovulation which occurs within a remarkably constant time period depending on the species under investigation. For example, in heifers this period is 4 to 7 days (Willet, 1950); in sheep, 3 days (Dutt \& Casida, 1948); and in swine, 6 to 7 days (Ulberg, Grummer \& Casida, 1951). Although these animals ovulate and can be mated at this time, conception rate is usually low (Nellor \& Cole, 1956; Trimberger \& Hansel, 1955). Recently, Dziuk (1960) reported that the withdrawal of chronically administered oral progesterone resulted in synchronous oestrus and, when mice were mated at this time, normal conception usually occurred. Little information on oestrous activity in rats following progesterone withdrawal has been reported. Some data by Pincus (1956) and Saunders (1958) suggest an inhibition of mating and thus of conception. In the preliminary study, we found that ten Long-Evans rats, treated daily with $10 \mathrm{mg}$ of progesterone for 14 days and bred on the 17 th day showed $100 \%$ conception and normal litters.

* Present address: Department of Obstetrics and Gynecology, Stanford University School of Medicine, Palo Alto, California, U.S.A. 
To verify this observation and to determine effects upon mating performance of female rats after progesterone withdrawal was the object of this experiment.

\section{MATERIALS AND METHODS}

Mature female rats were used in all tests. In Trial I, five Castle rats and five Sprague-Dawley rats, all with a history of poor breeding performance (Table I),

TABLE 1

INFLUENGE OF PROGESTERONE WITHDRAWAL ON TIME OF OVULATION AND MATING IN MATURE FEMALE RATS

\begin{tabular}{|c|c|c|c|c|c|}
\hline Rat No. & Treatment & $\begin{array}{l}\text { Refusals to } \\
\text { accept males } \\
\text { during } 6 \text { wh } \\
\text { prior to } \\
\text { treatment* } \\
(\text { No. })\end{array}$ & $\begin{array}{c}\text { Vaginal } \\
\text { smear at } \\
\text { start of } \\
\text { treatment }\end{array}$ & $\begin{array}{l}\text { Interval from } \\
\text { treatment } \\
\text { to dioestrous } \\
\text { smear } \\
\text { (days) }\end{array}$ & $\begin{array}{c}\text { Interval } \\
\text { after } \\
\text { treatment } \\
\text { until plug } \\
\text { or spermatozoa } \\
\text { (days) }\end{array}$ \\
\hline $\begin{array}{c}\text { Trial I: } \\
\text { B74 } \\
\text { B54 } \\
\text { B55 } \\
\text { B56 } \\
\text { B32 } \\
\text { W68 } \\
\text { W60 } \\
\text { W58 } \\
\text { W56 } \\
\text { W24 }\end{array}$ & $\begin{array}{c}10 \mathrm{mg} \\
\text { progesterone }\end{array}$ & $\begin{array}{l}4 \\
4 \\
3 \\
2 \\
7 \\
4 \\
3 \\
2 \\
\end{array}$ & $\begin{array}{l}\mathrm{O} \\
\mathrm{C} \\
\text { Leac } \\
\mathrm{C} \\
\text { Le } \\
\mathrm{C} \\
\mathrm{O}-\mathrm{I} \\
\mathrm{O}-\mathrm{l} \\
\mathrm{O} \\
\mathrm{C}\end{array}$ & $\begin{array}{l}3 \\
4 \\
0 \\
4 \\
4 \\
4 \\
4 \\
2 \\
3 \\
3\end{array}$ & $\begin{array}{l}4 \\
4 \\
4 \dagger \\
4 \\
7 \\
4 \\
\pm \\
4 \\
4 \\
4\end{array}$ \\
\hline $\left.\begin{array}{c}\text { Trial II } \\
\text { W45 } \\
\text { W57 } \\
\text { W00 } \\
\text { W68 } \\
\text { W64 } \\
\text { W72 }\end{array}\right\}$ & $\begin{array}{c}10 \mathrm{mg} \\
\text { progesterone }\end{array}$ & & $\begin{array}{l}\text { C } \\
\text { Le } \\
\text { Leac } \\
\text { Leac } \\
\text { O } \\
\text { O-l }\end{array}$ & $\begin{array}{l}4 \\
5 \\
7 \\
0 \\
3 \\
2\end{array}$ & $\frac{\frac{4}{4}}{\frac{4}{4}}$ \\
\hline $\left.\begin{array}{l}\text { W46 } \\
\text { W50 } \\
\text { W73 } \\
\text { W63 } \\
\text { W47 } \\
\text { W75 }\end{array}\right\}$ & $\begin{array}{c}0.2 \mathrm{ml} \\
\text { oil }\end{array}$ & & $\begin{array}{l}\mathrm{Le} \\
\mathrm{Le} \\
\mathrm{Le} \\
\mathrm{G} \\
\mathrm{O} \\
\text { Leac }\end{array}$ & & $\begin{array}{l}\overline{-} \\
\overline{-} \\
\frac{4}{-}\end{array}$ \\
\hline
\end{tabular}

* Failure to observe spermatozoa in vaginal smear on morning after $\delta$ introduced when $q$ was in pro-oestrus.

+ No spermatozoa or plug found, but normal fertile ova were found at autopsy.

I Sacrificed on 6 th day after termination of treatment - uncleaved ova present.

$$
\begin{array}{cc}
\mathrm{Le}=\text { metoestrus } & \mathrm{G}=\text { oestrus } \\
\mathrm{O}=\text { pro-oestrus } & \text { Leac }=\text { dioestrus } \\
\mathrm{O}-\mathrm{l}=\text { late pro-oestrus } &
\end{array}
$$

were used as the treated group. Based on the changes observed in the vaginal smears, which were taken at least four times a week for 6 weeks prior to treatment, it appeared that these animals were cycling normally, though they were not mating at the times of observed pro-oestrus. During this trial, the remainder of the breeding-colony females, which were placed with males at each time of observed pro-oestrus during this same 8-week period, supplied the control 
data. In Trial II, the regularity of cycles was not established during the 6 weeks preceding the trial since these animals had been culled earlier due to age or poor performance. Of the twelve Sprague-Dawley rats, which made up the treated and control groups in this trial, seven were 17 months of age and five were between 9 and 12 months of age. The younger five had been culled because of a history of irregular cycles, refusals to mate or failure to rear young. In all cases, animals were maintained on an automatically controlled 14-hr-light, 10-hr-dark regime.

In both trials, the treated animals were injected subcutaneously once a day between 3 and 4 p.m. for 14 days with $10 \mathrm{mg}$ of progesterone in $0.2 \mathrm{ml}$ vegetable oil. During this time, smears were also taken. The six control animals in Trial II received $0.2 \mathrm{ml}$ of the oil medium. All injections were terminated on Day 14 . On the last day of treatment in Trial I, four animals, selected at random, were placed individually in cages with two to four males. The vaginal smears of these females were checked each morning for copulation plugs or the presence of spermatozoa. Vaginal smears for all animals were observed and recorded each afternoon. On the 3rd day after withdrawal, all animals, regardless of stage of the oestrous cycle as determined by vaginal smear, were placed individually in cages with two to four males. The occurrence of mating was determined by the presence of spermatozoa in the vaginal smear or a copulation plug on the following morning.

In all trials, the same males were used both preceding and following treatment.

\section{OBSERVATIONS}

Although animals showed various vaginal smears on the 1st day of injection in both series, by the 4th day all but two in the treated groups had become dioestrous (Table 1). During the treatment, a thick vaginal mucus formed. Since the vaginal smears contained few characteristic cell types, it was difficult to interpret accurately the stage of the cycle by this method. In not one case, however, was there a clear-cut pro-oestrous or oestrous smear until after treatment was stopped.

From Table 1, the influence of progesterone withdrawal on mating is obvious. In Trial I, all but three females showed evidence of mating on the 4th day after the end of treatment, whereas during the 6 weeks before, despite repeated attempts to breed, most of these same animals had refused to accept the male. Since evidence of mating sometimes can be overlooked, two of the three exceptions were sacrificed. The reproductive tracts were removed and flushed with Eagle's medium. Microscopic examination of the washings from one animal (B55) showed normally developed, fertile ova, indicating mating on the evening of the 3rd day. The second animal had uncleaved tubal ova, indicating ovulation but not mating. The remaining exception showed a pro-oestrous smear again on the 6th day after treatment withdrawal and mated at this time.

The percentage of animals mating after treatment compared to normal mating percentages of colony animals provides a striking comparison. The control data based on 155 matings attempted with only those females shown to 
be in pro-oestrus, reveal that only $47 \%$ mated during the 6 weeks prior to and the 2 weeks during treatment. At this time, in order to obtain six females with a pro-oestrous smear, it was necessary to examine about forty-five mature females, which indicates that some of the colony animals were exhibiting abnormal cycles. In contrast to the $47 \%$ mating of colony females, $80 \%$ of the treated animals mated on the 4 th day and $90 \%$ within 1 week after treatment in Trial I. Litter data taken from this trial showed no evidence of abnormalities of the foetuses in size, sex ratio, effect on secondary sex characteristics or length of gestation.

The six oil-injected controls in Trial II were of comparable age to the treated group. Only one animal in the control group, compared to four out of six in the treated group, mated. Data from normal animals in the breeding colony at this time (summer) showed a decline in percentage mating among all females as well as a higher incidence of aberrant cycles.

\section{DISCUSSION}

The results of this experiment show that oestrus and ovulation can be synchronized in rats following the withdrawal of progesterone. Furthermore, the consistent finding of a higher mating percentage after treatment than before suggests that prior progesterone treatment may stimulate oestrous behaviour.

It is interesting to speculate on the mechanisms causing synchronization of oestrus and ovulation as a result of progesterone withdrawal. To account for this response, one must consider the effect of this steroid on the anterior pituitary. The ability of progesterone to inhibit the release of pituitary gonadotrophins has been shown in studies on parabiotic rats (Biddulph, Meyer \& Gumbrick, 1940). Van Rees (1959) reported a lowered serum IcsH level concomitant with unchanged pituitary level in female rats injected with 1 or $6 \mathrm{mg}$ of progesterone for 25 to 27 days, a result which he interpreted as an inhibition of ICSH production. In addition, he observed that progesterone administered at the same levels increased the FSH content of the pituitary, but decreased the 'readiness' of the pituitary to release FSH. This type of evidence could suggest that the withdrawal of progesterone initiates the release of FSH from the pituitary within a fairly uniform time interval for each individual. As a consequence, follicular maturation and ovulation are synchronized.

That progesterone administration or withdrawal could explain the increased mating percentage observed in these studies by an influence upon sexual behaviour is suggested by the results of several investigations. Progesterone plays an important role in the induction of oestrous behaviour in several species; for example, the rat (Beach, 1942), guinea-pig (Dempsey, Hertz \& Young, 1936) and sheep (Robinson, 1954). A recent and detailed study of Kawakami \& Sawyer (1960) associated changes in brain activity with progesterone administration in oestrous or oestrogen-primed female rabbits. Following the injection of this steroid they observed an immediate reduction of $E E G$ arousal and $E E G$ after-reaction thresholds lasting a few hours. The thresholds subsequently were elevated, but rebounded to lower levels after $24 \mathrm{hr}$. Behavioural oestrus and pituitary activation were related to the time of reduced thresholds. 
Supported in part by a grant-in-aid from the Syntex Animal Products Company New York City, New York.

\section{REFERENCES}

BEACH, F. A. (1942) Importance of progesterone to induction of sexual receptivity in spayed female rats. Proc. Soc. exp. Biol., N.Y. 51, 369.

Biddulph, G., Meyer, R. K. \& Gumbrick, D. L. (1940) The influence of estriol, estradiol and progesterone on the secretion of gonadotropic hormones in parabiotic rats. Endocrinology, 26, 280.

Dempsey, E. W., Hertz, R. \& Young, W. C. (1936) The experimental induction of oestrus (sexual receptivity) in the normal and ovariectomized guinea-pig. Amer. F. Physiol. 116, 201.

Durr, R. \& CAsida, L. E. (1948) Alteration of the estrual cycle in sheep by use of progesterone and its effect upon subsequent ovulation and fertility. Endocrinology, 43, 208.

Dzıuk, P. (1960) Inhibition and synchronization of mating in the mouse by oral administration of progestins. Endocrinology, 66, 898.

Kawakami, M. \& Sawyer, C. H. (1960) Neuroendocrine correlates of changes in brain activity thresholds by sex steroids and pituitary hormones. Endocrinology, 65, 652 .

Nellor, J. \& Cole, H. H. (1956) The hormonal control of estrus and ovulation in the beef heifer. $\mathcal{J}$. Anim. Sci. 15, 650.

Pincus, G. (1956) Some effects of progesterone and related compounds upon reproduction and early development in mammals. Acta endocr., Copenhagen, 23, Suppl. 28, p. 18.

Robinson, T.J. (1954) The necessity for progesterone with estrogen for the induction of recurrent estrus in the ovariectomized ewe. Endocrinology, 55, 403.

Saunders, F. J. (1958) The effects of several steroids on fecundity in female rats. Endocrinology, 63, 561.

Trimberger, G. \& Hansel, W. (1955) Conception rate and ovarian function following estrus control by progesterone injections in dairy cattle. 7. Anim. Sci. 14, 224.

Ulberg, L., Grummer, R. H. \& Casida, L. E. (1951) The effects of progesterone upon ovarian function in gilts. 7. Anim. Sci. 10, 665 .

VAN ReEs, G. P. (1959) I.C.S.H. and F.S.H. content of anterior pituitary and blood serum. Acta physiol. pharm. néerl. 8, 195.

Willet, E. (1950) The fertility of heifers following administration of progesterone to alter the estrual cycle. 7. Dairy Sci. 33, 381. 